\title{
THE EXTENT OF THE FINANCIAL ACCOUNTING SYSTEM RESPONSE IN JORDAN OF THE APPLICATION OF THE INTERNATIONAL ACCOUNTING STANDARDS
}

\section{DR. OTHMAN HUSSEIN OTHMAN}

ISRA University, Jordan

\begin{abstract}
The study aimed to identify the response of the financial accounting system in Jordan to the application of international standards of accounting through the application of accounting and financial operations and change management. The study sample consisted of (150) workers in the Directorate of Government Financial Management Information System in Jordan. A questionnaire was used to collect the needed data. The researcher adopted the descriptive analytical approach and reached a conclusion that the accounting and financial operations and change management contribute to the effectiveness of the government accounting system represented by the Government Financial Management Information System (GFMIS) in achieving its goals. The dimension of accounting and financial operations came in a medium degree, as the dimension of Change Managing was with a medium degree as well. The study recommended the necessity of conducting a periodic evaluation of the GFMIS system and identifying problems facing its users through (feedback) regarding development of the system and its applications.

KEYWORDS: Financial Accounting System - International Accounting Standards
\end{abstract}

Received: Jun 09, 2020; Accepted: Jun 29, 2020; Published: Aug 01, 2020; Paper Id.: IJMPERDJUN2020565

\section{INTRODUCTION}

During the last decades, the world witnessed successive economic developments that had clear repercussions on the business environment and the economic organizations it contains, so the activities of some economic units extended beyond the regional borders and their branches spread throughout the world, and giant economic blocs appeared and the interest in foreign investment, especially in the developing country, increased.

It should be noted that the different accounting practices from one country to another, and the resulting risks have led to increased interest in accounting standardization that leads to the standardization of language and the adoption of single concepts, terms and definitions. In addition to the standardization of principles and methods of work, preparation and disclosure of information, as well as the standardization of financial statement forms, and production of useful information, with comparable credibility, assisting its users in making decisions, and providing appropriate and internationally accepted financial statements (Bruggerman at all, 2013).

As countries around the world have different practices in preparing financial and accounting reports, which stem from different legal, cultural, economic, social and political contexts, this variation in financial and accounting reporting makes it extremely difficult for users of financial and accounting reports to integrate this information and make comparisons between listed companies in different countries (Horton at all, 2013). 
On the other hand, there is widespread interest in international accounting standards, their economic and social consequences and their future. However, more research is needed to address the multifaceted issues and perspectives that relates to international accounting standards (Ahmed, 2013). Since the emergence of the International Financial Reporting Standards in April 2001, about 150 countries around the world have abandoned their various domestic or regional standards in order to adopt or approach international financial reporting standards (Umoren \& Enang2015). In this sense, the introduction of the international financial reporting standards for listed companies in many countries around the world is one of the most important regulatory developments in the history of accounting, which was welcomed despite the differences (Odia \& Ogiedu, 2013). However, the adoption of the IFRS is expected to enhance the efficiency of the stock market by reducing information aberration (Balakrishnan \& Yang, 2014).

Here it is worth noting the need to find a point of convergence between the standards applied in preparing financial reports at the local level and international standards for financial reporting, including international accounting standards, as a result of the increasing globalization at the level of local economies. However, in order to achieve a greater degree of transparency at the global level to allow entry into the framework of global accountability, we must work to have a free market economy, including the availability of the institutions necessary for the required compatibility to occur. Jordanian economy is still under the government sponsorship that limits its independence and flexibility in decisionmaking through the imposed governmental sponsorship of the economy. Therefore, economic institutions still fail between ineffective individual decisions and the centrality of strict management far from any harmony (Al-Hunaity, 2015). Therefore, this type of economic system is a traditional system that does not keep pace with global economic developments and the requirements of global trade, which considers the necessity of easing the rules, restrictions and routine procedures in order to reform the local economic systems. Therefore, confidence in financial investments must be supported, perhaps by creating a mechanism to achieve compatibility between the financial accounting system in Jordan and international accounting standards (Al-Kilani, 2019).

Perhaps one of the most important justifications for conducting this study is the steady increase in the adoption of international financial reporting standards throughout the world, which may be related to the benefits provided by these reports. Some of the specific benefits of adopting international financial reporting standards in the literature are the production of high-quality financial reports, in addition to global economic and financial integration (BoliBok, 2014), and on the other hand the integration of the global capital market or cross-border listing, and improving the comparison of financial reports, with access to foreign direct investment (Gordon at all, 2012).

Based on all of the above, research on knowing the extent of the financial accounting system in Jordan response to the application of the international accounting standards has its justifications, in light of what is presented on the global scene in accordance with the established standards for preparing financial reports, including international accounting standards. Among those justifications also that those in charge of the financial accounting system in Jordan become more able to keep pace with the global level within the new system of economics.

\section{PROBLEM OF THE STUDY}

The application of international accounting standards would meet the needs of local and foreign investors alike, and the success of this application is bound by the conditions and procedures that ensure a smooth and flexible transition from the established financial accounting system to the new financial accounting system. 
In this context, several studies have examined the extent to which countries in which these studies were conducted are able to apply international accounting standards and international financial reporting standards, and the extent of their suitability to the environment of these countries. Yousef (2016) study aimed to demonstrate the compatibility of the new financial accounting system in Jordan with international accounting standards. In the same context, the Dahbey (2017) study came to demonstrate the imperatives of implementing international accounting standards in Jordan, and the extent of their application, in addition to a statement of the obstacles that limit their applicability and the study recommended some solutions and suggestions to overcome these obstacles. Moreover, Sadiq (2018) study revealed the extent of compatibility of accounting standards in Saudi Arabia with international standards and the development of mechanisms to harmonize Saudi accounting standards.

Since the financial accounting system in Jordan needs responsible controls and different requirements at the economic level for countries that enjoy high economies, and to the organization and efficiency in accounting work in accordance with international accounting standards, in addition to what was mentioned in previous studies in this field, the idea took root in the need to conduct a study related to disclosure of the response of the financial accounting system in Jordan to the application of international accounting standards, and therefore, the researcher determines the problem of his study with the following main question:

To what extent does the financial accounting system in Jordan respond to the application of international accounting standards, and what are the most important obstacles that prevent the application of these standards?

\section{QUESTIONS OF THE STUDY}

- What is the extent of the response of the financial accounting system in Jordan to the application of international accounting standards in relation to accounting and financial operations?

- What is the extent of the response of the financial accounting system in Jordan to the application of international accounting standards in relation to change management?

\section{STUDY HYPOTHESES}

- Accounting and financial operations do not contribute to the effectiveness of the government accounting system represented by the Government Financial Management Information System (GFMIS) in achieving its goals.

- Change Management does not contribute to the effectiveness of the government accounting system represented by the Government Financial Management Information System (GFMIS) in achieving its goals.

\section{OBJECTIVES OF THE STUDY}

- Identifying the extent of response of the financial accounting system in Jordan to the application of international accounting standards through the application of accounting and financial operations according to the international standards.

- Identifying the extent of response of the financial accounting system in Jordan to the application of international accounting standards through the application of change management according to international standards. 


\section{SIGNIFICANCE OF THE STUDY}

- The urgent need to implement international accounting standards and find the appropriate mechanism to achieve compatibility between them and the accounting system in force in Jordan.

- Shedding light on the mechanisms of applying international financial reporting standards to advance the institutions of Jordan so that they have the ability to compete, whether locally or internationally.

- This study may contribute to revealing the extent of response of the financial accounting system in Jordan to the application and adoption of international accounting standards.

- The study may contribute to monitoring and identifying the most important economic benefits that may result if international accounting standards are applied.

\section{TERMS OF THE STUDY}

\section{Financial Accounting System}

It is the set of material and moral elements used in the implementation of the accounting work, organization and completion of the full accounting cycle (Garbowski at all, 2019). Accordingly, the accounting system is the set of actions, procedures, and arrangements by which data transactions and financial statements are collected, analyzed, classified, summarized and interpreted during the accounting period (Dillard \& Vinnari, 2019).

\section{International Accounting Standards}

It is a set of foundations, controls and directives that aim to address general or private accounting issues in accordance with generally accepted accounting principles (Muda, 2017). Since 2001 a new set of standards known as the International Financial Reporting Standards (IFRSs) has been introduced and issued by the International Accounting Standards Board (Ezeagba, 2017).

\section{IFRS}

A set of International Accounting Standards that explain how to show specific types of transactions and events in the financial statements. International standards are prepared and issued by the International Accounting Standards Board (IASB), and they define precisely how accountants maintain their accounts and methods of registration. International standards were established in order to obtain a unified accounting language, so that business and accounting can be understood from company to company and from country to country (Huang, 2020). The importance of international standards is to prepare financial reports while maintaining stability and transparency throughout the financial world. This allows companies and individual investors to make informed financial decisions, because they are able to see exactly what is happening with the company they want to invest in (Pedroso \& Gomes, 2020).

\section{DELIMITATIONS OF THE STUDY}

The study aims to identify the response of the financial accounting system in Jordan to the application of international accounting standards, and a set of dimensions are identified and will be studied in the field side of the study. The study was applies in 2020 in The Hashemite Kingdom of Jordan, represented by the Directorate of Government Financial Information Management System. The study was applied on the workers in the administration of the Government Financial Management Information System in Jordan. 


\section{PROCEDURES OF THE STUDY}

\section{Methodology of the Study}

The researcher adopted the descriptive analytical approach through investigating the opinions of the study sample to know their opinions on the extent of the financial accounting system response in Jordan to apply the international standards.

\section{Sample of the Study}

The study sample consisted of (150) workers in the Directorate of Government Financial Information Management System in Jordan. The sample size was determined based on the law of the minimum sample selection.

\section{Instrument of the Study}

To achieve the goals of the study, the researcher developed a questionnaire that included two dimensions with the aim of identifying the response of the financial accounting system in Jordan to implement international standards.

\section{Validity of the Questionnaire}

The validity of the questionnaire was confirmed using the internal consistency method to ensure the validity of the internal consistency of the questionnaire. The questionnaire was distributed to a pilot sample consisting of (50) individuals in the Directorate of Government Financial Information Management System, and then the correlation coefficients were calculated between the total score for each dimension and the overall degree of the questionnaire; The following table explains the procedures for calculating the validity of internal consistency.

Table 1: Pearson Correlation Coefficients

\begin{tabular}{|l|c|c|}
\hline \multicolumn{1}{|c|}{ Dimensions } & $\begin{array}{c}\text { Correlation } \\
\text { Coefficients }\end{array}$ & Value of Sig. \\
\hline $\begin{array}{l}\text { Accounting and } \\
\text { Financial Operations }\end{array}$ & $0.741 * *$ & 0.000 \\
\hline Change Management & $0.809 * *$ & 0.000 \\
\hline
\end{tabular}

It is clear from the previous table that the correlation coefficients for each dimension of the response of the accounting system ranged between $(0.809$ - 0.741) degrees, which are high correlation coefficients, and it is also statistically significant at the level of significance $(0.05)$.

\section{Reliability of the Questionnaire}

To verify the reliability of the questionnaire, the researcher followed the Cronbach's Alpha method, which requires calculating the correlation of the items with each other. Table (2) shows the reliability coefficients of the questionnaire and each of its dimensions using the Cronbach's Alpha equation.

Table 2: Cronbach's Alpha Reliability Coefficients

\begin{tabular}{|l|c|}
\hline \multicolumn{1}{|c|}{ Dimensions } & Cronbach's Alpha \\
\hline Accounting and Financial Operations & 0.726 \\
\hline Change Management & 0.722 \\
\hline Total Reliability & 0.872 \\
\hline
\end{tabular}

It is clear from the previous table that the total reliability coefficient for the questionnaire reached (0.872), which is a high reliability coefficient that indicates that the questionnaire has a high degree of reliability and can be relied upon in the field application of the study. 


\section{Discussing the Questions of the Study}

\section{The First Question}

What is the extent of the response of the financial accounting system in Jordan to the application of international accounting standards in relation to accounting and financial operations?

To answer this question, the arithmetic means and the standard deviations of the responses of the sample members for each item of the dimension of the accounting and financial operations were calculated according to the descending order, and the following table shows that.

Table 3: Means and Standard Deviations for the Accounting and Financial Dimension

\begin{tabular}{|c|c|c|c|c|}
\hline Items & Mean & $\begin{array}{l}\text { Standard } \\
\text { Deviation }\end{array}$ & Rank & $\begin{array}{l}\text { Extent of } \\
\text { Response }\end{array}$ \\
\hline $\begin{array}{l}\text { The system is considered through budget management } \\
\text { applications as an effective tool to monitor the allocations } \\
\text { monitored within the budget law. }\end{array}$ & 3.43 & 0.634 & 1 & High \\
\hline $\begin{array}{l}\text { The system is developing a mechanism to prepare a budget for } \\
\text { approved medium-term expenditures and revenues. }\end{array}$ & 3.41 & 0.732 & 2 & High \\
\hline $\begin{array}{l}\text { The system provides a mechanism to monitor project performance } \\
\text { and costs with absolute accuracy to issue various reports. }\end{array}$ & 3.27 & 0.872 & 3 & Medium \\
\hline $\begin{array}{l}\text { The system is characterized by adopting the monetary foundation } \\
\text { of ease in the conduct of its applications. }\end{array}$ & 3.23 & 0.688 & 4 & Medium \\
\hline $\begin{array}{l}\text { Classification of government job formations in the system helps } \\
\text { reduce the deviation between expected and actual costs when } \\
\text { preparing a budget. }\end{array}$ & 3.21 & 0.609 & 5 & Medium \\
\hline $\begin{array}{l}\text { The system helps cash management to facilitate the achievement } \\
\text { and conduct of electronic bank reconciliation. }\end{array}$ & 3.20 & 0.797 & 6 & Medium \\
\hline $\begin{array}{l}\text { System applications help cash management to develop a financial } \\
\text { plan for monthly expenditures. }\end{array}$ & 3.18 & 0.732 & 7 & Medium \\
\hline Total & 3.28 & 0.799 & \multicolumn{2}{|c|}{ Medium } \\
\hline
\end{tabular}

From a review of Table (3), it is clear that the total mean for the responses of the sample members on all the items of the dimension of accounting and financial operations has reached (3.28), which is medium. The mean for the items of the dimension of the accounting and financial operations ranged between (3.18 - 3.43) between the lowest and the highest mean. This result can be explained by the fact that the response of the financial accounting system in Jordan to the application of international accounting standards need to establish a mechanism for preparing the budget for medium-term expenditures and revenues through reliance on a monetary basis, and the system needs to monitor the performance of projects and their costs while developing a financial plan for monthly expenditures.

\section{The Second Question}

What is the extent of the response of the financial accounting system in Jordan to the application of international accounting standards in relation to change management?

To answer this question, the arithmetic means and the standard deviations of the responses of the sample members for each item of the dimension of the Change management were calculated according to the descending order, and the following table shows that. 
Table 4: Means and Standard Deviations for the Change Management Dimension

\begin{tabular}{|c|c|c|c|c|}
\hline Items & Means & $\begin{array}{l}\text { Standard } \\
\text { Deviation }\end{array}$ & Rank & $\begin{array}{l}\text { Extent of } \\
\text { Response }\end{array}$ \\
\hline $\begin{array}{l}\text { Change management continuously monitors the qualification of } \\
\text { system users. }\end{array}$ & 3.39 & 0.723 & 1 & High \\
\hline $\begin{array}{l}\text { Change Management provides system guides and introductory } \\
\text { flyers and how to work on it. }\end{array}$ & 3.36 & 0.702 & 2 & High \\
\hline $\begin{array}{l}\text { The system helps measure application quality of the system } \\
\text { through feedback reports. }\end{array}$ & 3.21 & 0.801 & 3 & Medium \\
\hline $\begin{array}{l}\text { The system contributes to standardizing financial and accounting } \\
\text { databases with all government departments and institutions. }\end{array}$ & 3.19 & 0.729 & 4 & Medium \\
\hline $\begin{array}{l}\text { The system facilitates investigation and control operations } \\
\text { through its work to standardize the form of reports issued by it to } \\
\text { all government departments and institutions. }\end{array}$ & 3.15 & 0.673 & 5 & Medium \\
\hline $\begin{array}{l}\text { System applications facilitate the speed of financial procedures } \\
\text { for users }\end{array}$ & 3.13 & 0.737 & 6 & Medium \\
\hline $\begin{array}{l}\text { The Change Management studies the financial and accounting } \\
\text { processes on an ongoing basis to redesign and engineering them } \\
\text { to suit developments. }\end{array}$ & 3.11 & 0.766 & 7 & Medium \\
\hline Total & 3.22 & 0.783 & & edium \\
\hline
\end{tabular}

From a review of Table (4), it is clear that the total mean for the responses of the sample members on all the items of the dimension of change management has reached (3.22), which is medium. The mean for the items of the dimension of the change management ranged between (3.11 - 3.39) between the lowest mean. This result can be explained by the fact that the response of the financial accounting system in Jordan at the level of change management requires measuring the quality of applications to the system through feedback reports, unifying the financial and accounting databases with all government departments and institutions. Moreover, the verification and control in the financial and accounting procedures and redesigning and engineering them to suit with the international accounting standards.

\section{Discussing the Hypotheses of the Study}

\section{The First Hypothesis}

Accounting and financial operations do not contribute to the effectiveness of the government accounting system represented by the Government Financial Management Information System (GFMIS) in achieving its goals.

To verify the hypothesis, one-sample T-Test was used to find out the effectiveness of the financial accounting system in Jordan through the dimension of accounting and financial operations. The results were as shown in the following table:

Table 5: One-Sample T-Test

\begin{tabular}{|l|c|c|c|c|c|}
\hline \multicolumn{1}{|c|}{ Dimension } & $\begin{array}{c}\text { Value of Calculated } \\
(\mathbf{t})\end{array}$ & Means & $\begin{array}{c}\text { Standard } \\
\text { Deviation }\end{array}$ & $\begin{array}{c}\text { Value of } \\
\text { Significance }\end{array}$ & Decision \\
\hline $\begin{array}{l}\text { Accounting and } \\
\text { Financial Operations }\end{array}$ & 63.807 & 4.717 & 0.318 & 0.000 & Rejected \\
\hline
\end{tabular}

The results in Table (5) indicate that the value of significance is less than the alpha significance value (5\%), and therefore we reject the zero hypothesis and accept the alternative hypothesis which states that: Accounting and financial operations contribute to the effectiveness of the government accounting system represented by the Government Financial Management Information System (GFMIS) in achieving its goals. The interpretation of this result is that the accounting system follows the procedures of international accounting standards in terms of contracting contracts and financial reports 
for the industrial and commercial sectors, in addition to investing in establishments. All of this contributed to the response of the financial accounting system in Jordan for global accounting requirements.

\section{The Second Hypothesis}

Change Management does not contribute to the effectiveness of the government accounting system represented by the Government Financial Management Information System (GFMIS) in achieving its goals.

To verify the hypothesis, one-sample T-Test was used to find out the effectiveness of the financial accounting system in Jordan through the dimension of Change Management. The results were as shown in the following table:

Table 6: One-Sample T-Test

\begin{tabular}{|c|c|c|c|c|c|}
\hline Dimension & Value of Calculated (t) & Means & Standard Deviation & Value of Significance & Decision \\
\hline Change Management & 17.292 & 3.735 & 0.5 .3 & 0.000 & Rejected \\
\hline
\end{tabular}

The results in Table (5) indicate that the value of significance is less than the alpha significance value (5\%), and therefore we reject the zero hypothesis and accept the alternative hypothesis which states that: Change Management contributes to the effectiveness of the government accounting system represented by the Government Financial Management Information System (GFMIS) in achieving its goals. The interpretation of this result is that the accounting system takes the change management approach as an introduction to making comprehensive and profound changes in the accounting system to develop the financial system, while applying total quality management as a recent entry to change in the government financial information management system in Jordan. Moreover, employing modern principles and methods in organization management. And spreading the culture of quality as an urgent necessity required by the conditions of the times and its data in all sectors.

\section{RECOMMENDATIONS}

- Working to keep pace with developments in the field of financial accounting operations and change management and to develop future plans to accommodate the increase in the volume of data stored.

- The necessity of conducting a periodic evaluation of the GFMIS system and identifying the problems facing its users through (feedback) regarding development of the system and applications.

- Paying attention to the approaches to change management such as comprehensive quality, organizational culture and strategic planning processes.

- Creating reports that meet the needs of users or the needs of the regulatory and legislative authorities in the financial accounting system in Jordan.

- Working on developing and approving a cost card for each project to determine the actual costs and performance and achievement ratios for these projects.

- Developing reports that help evaluate the optimal use of public money.

- The speed of providing technical support, whether technical technology or technical support by speeding up the internet lines to avoid slow work.

- Human technical support by holding training workshops and courses by forming qualified cadres and support teams. 
- $\quad$ Automating all system procedures, reducing paper and manual work.

\section{REFERENCES}

1. Ahmed, K. (2013). A Meta-Analysis of IFRS Adoption Effects. The International Journal of Accounting 48, 173-217.

2. Al-Hunaity, Khalid. (2015). Evaluation of the Effectiveness of Accounting System in Jordanian Government Sector and the possibility of Developed A Field Study: Budget Department and Directorate of Governmental Financial Management Information System (GFMIS), Master Thesis, Jerash University, Jordan.

3. Al-Kilani, Hafiz. (2019). The role of international accounting standards in developing accounting information systems, Master Thesis, University of Aleppo.

4. Balakrishnan, K., Li, X., and Yang, H. (2014). Mandatory Financial Reporting and Voluntary Disclosure: Evidence from Mandatory IFRS Adoption. Draft Manuscript.

5. BoliBok, P. (2014). The impact of IFRS on the value relevance of accounting data of banks listed on the Warsaw stock exchange. Copernican Journal of Finance and Accounting, 3(1), 33-43.

6. Bruggermann, U, Hitz, J, and Selhorn, T. (2013). Intended and Unintended Consequences of Mandatory IFRS Adoption: A Review of Extant Evidence and Suggestions for Future Research. European Accounting Review 22 (1), 1-37.

7. Dahbey, Dina. (2017). The extent of application of international accounting standards in Syria. Master Thesis, University of Damascus.

8. Dillard, J., \&Vinnari, E. (2019). Critical dialogical accountability: From accounting-based accountability to accountabilitybased accounting. Critical Perspectives on Accounting, 62, 16-38.

9. Ezeagba, C. (2017). Financial reporting in small and medium enterprises (SMEs) in Nigeria. Challenges and options. International Journal of Academic Research in Accounting, Finance and Management Sciences, 7(1), 1-10.

10. Garbowski, M., Drobyazko, S., Matveeva, V., Kyiashko, O., \& Dmytrovska, V. (2019). Financial accounting of E-business enterprises. Academy of Accounting and Financial Studies Journal, 23, 1-5.

11. Gordon, L., Loeb, M., \& Zhu, W. (2012). The impact of IFRS adoption on foreign direct investment. Journal of Accounting Public Policy, 31(4), 89-119.

12. Horton, J., Serafeim, G., and Serafeim, J. (2013). Does Mandatory IFRS Adoption Improve the Information Environment? Contemporary Accounting Research 30 (1), 388-423.

13. Huang, J. (2020, April). Development of Computer Technology Application in Financial Accounting. In Journal of Physics: Conference Series (Vol. 1533, No. 2, p. 022021). IOP Publishing.

14. Kountur, Ronny, and Yuanyuan Huo. "The qualifications of accounting profession as required by employer." Management (IJFM) 2.4 (2013): 7-14.

15. Moudud-Ul-Huq, Syed, and PanuelRozario Prince. "Practice of human resource accounting in banking sector of Bangladesh." International journal of accounting and financial management research (2012).

16. Muda, I., Wardani, D. Y., Maksum, A., Lubis, A. F., Bukit, R., \& Abubakar, E. (2017). the influence of human resources competency and the use of information technology on the quality of local government financial report with regional accounting system as an intervening. Journal of Theoretical \& Applied Information Technology, 95(20).

17. Odia, J. O., \&Ogiedu, K. O. (2013). IFRS adoption: Issues, challenges and lessons for Nigeria and other adopters. Mediterranean Journal of Social Sciences, 4(3), 389-399. 
18. Prajapati, M., Ritambhara Singh, and Dilip Vahoniya. "A Study on Conceptual Framework of Human Resource Accounting in India." International Journal of Human Resource Management and Research (IJHRMR) 6.3 (2016): 7-12.

19. Pedroso, E., \& Gomes, C. F. (2020). The effectiveness of management accounting systems in SMEs: a multidimensional measurement approach. Journal of Applied Accounting Research.

20. Sadiq, Ali. (2018). The impact of the compatibility of Saudi accounting standards with international accounting standards on the development of the accounting profession in the Kingdom of Saudi Arabia. Twelfth Symposium, King Saud University, Riyadh, Saudi Arabia 9-18 May 2010.

21. Umoren, A. O., \&Enang, E. R. (2015). IFRS adoption and value relevance of financial statements of Nigerian listed banks. International Journal of Finance and Accounting, 4(1), 1-7.

22. Vohra, P. S., and Vipla Chaudhary. "Human Resource Accounting Practices Leads Firm Performance." International Journal of Business and General Management (IJBGM) ISSN (P) (2014): 2319-2267.

23. Yousef, Rafek. (2016). Financial accounting system between responding to international standards and application requirements. Master Thesis. Algeria University. 